\title{
YOUTH CULTURE AND EUROPEAN INTEGRATION IN GERMANY: BACK TO EUROPEAN BASICS? ${ }^{1}$
}

\author{
Gudrun Quenzel $\left.\right|^{2}$ \\ (Universidad de Duisburg) \\ Mathias Albert ${ }^{3}$ \\ (Universidad de Bielefeld)
}

\section{RESUMEN}

Basándose en datos de la encuesta respresentativa sobre los jóvenes en Alemania, este artículo destaca tendencias significativas en las actitudes hacia la integracíon europea a lo largo de un periodo relativamente corto. La investigación de estas actitudes cambiantes hace pensar que estos cambios podrían señalar más que una simple reacción a corto plazo hacia acontecimientos políticos singulares una reorientación hacia la emergente conceptualización de la integracíon europea como un proyecto de paz.

PALABRAS CLAVE: Actitudes políticas, jóvenes alemanes, integración europea.

\section{Introduction}

More than ever before, the project of European integration currently seems to be characterized by a feverish quest of the European Union to find out who and what it is and who and what it wants to be. Questions of a 'European identity' loom particularly large in the context of the debates on further EU enlargement

\footnotetext{
Publicación original (online): Asia Europe Journal, vol. 5, n 4, enero 2008, 529-540. With kind permission of Springer Science and Business Media / Con la amable cesión por parte de Springer Science and Business Media (Copyright).

2 Gudrun Quenzel is Lecturer at the Institute for Sociology at the University of Duisburg-Essen and one of the authors of the 2006 Shell Youth Survey. (gudrun.quenzel@uni-duisburg-essen.de)

3 Mathias Albert is Professor of Political Science at Bielefeld University and one of the Co-Directors of the 2002 and 2006 Shell Youth Surveys. (mathias.albert@uni-bielefeld.de)
} 
and particularly a possible accession of Turkey as an EU member. However, the debates on the depth of the integration process surrounding the proposed (and for the time being failed) project of a constitutional treaty, as well as the intensive debates on how the EU should assert and play its role on the stage of world politics (or as a 'normative power Europe'; see Manners 2002) can be seen as part of a discourse on a European identity.

As usual for symbolic constructions of collective identities, the discourse on a European identity is not always, and sometimes even not primarily, a discourse about what the EU wants to be in a 'positive' sense, but quite often also a discourse about who or what the 'Other' of Europe is (Diez 2004). It seems plausible to argue that on the level of metanarratives the quest for a European identity can be characterized as a move away from the founding narrative which was primarily of a temporal nature: Europe's Other at the beginning of the integration project was Europe's own past as a conflict-ridden and war-torn continent (Diez et al 2008). Much of the dynamics of the contemporary, multidimensional attempts to define a European identity can indeed be interpreted to anchor a European identity not in the difference from a temporal, but from variably either a cultural (e.g. the Muslim world), a geographic ('Bosporus', 'Urals'), or, less pronounced, a geostrategic other (the U.S., Russia).

The present contribution does neither seek to survey the enormous body of literature which now exists on the subject of a European identity, nor does it attempt to make a conceptual contribution of its own in this respect. However, it does start from a central conceptual assumption which is that in the long run no (discursive) constructions of a European identity (and the policies which are legitimized and framed by it) can be successfully upheld if they do not find a significant degree of resonance in European public opinion - a lesson taught to policy-makers quite forcefully in the Dutch and French referenda rejecting the constitutional treaty. Against this background, the aim of this contribution is not to add to the bourgeoning literature on European public opinion - a literature characterized by the two extremes of Eurostat surveys on the one hand and the theoretical discussion on whether there actually is such as thing as a European public opinion which is more than the sum of individual national public opinions. Rather, it is far more modest in that it will scrutinize attitudes towards Europe in but one European country, Germany, and in so doing only focus on attitudes among young people. The rationale for doing so is twofold: on a more general level, the attitudes and opinions of young people arguably have a seismographic function for future trends in society and can thus be taken as signposts of which discursive constructions can and which can not be successful. On a more specific level, the data to which we will refer below signal a quite significant shift in the attitudes towards Europe and the European Union among young people in Germany over recent years. We suggest that this shift in attitudes could actually mean more than a simple surge or ebbing regarding the opinion on specific issues. Rather, we argue that what we are witnessing here is a development which could point towards a re-orientation towards more traditional constructions of a European identity, i.e. Europe as a 'peace project' and not as an identity primarily asserting itself against a cul- 
tural or a geographic Other. In developing this argument, we do of course not claim to refer to a trend which could be seen as representative for European - or even German - public opinion as a whole. Yet we would claim that what we witness in the change of attitudes towards Europe among young people in Germany is a significant new development in terms of its quality which could - yet which by no means has to - serve as a role model for similar future developments in a broader European context as well. At the very minimum, what we witness is a development which could point a way out of those logics of European identity-construction which seek to construct a European identity primarily against ethnic, religious and geographic others, i.e. a development which could be seen to underpin more liberal and emancipatory pathways for the construction of a future European identity.

The present contribution will proceed in two steps. Primarily based on the results of the $15^{\text {th }}$ 'Shell Jugendstudie' (Shell Youth Survey) from 2006 (Deutsche Shell 2006) it will map attitudes of young people in Germany towards Europe and the European integration process, embedded also in the context of more general attitudes towards globalization and on Germany's role in the world. In a second step we will proceed in a more explorative fashion following the argument outlined so far and seek to relate these attitudes of young people in Germany towards the European integration process in particular and to the issue of the nature and contemporary state of this process in general.

\section{Attitudes towards the European integration process}

Europe enjoys a good deal of popularity among young people in Germany. When asked about their opinion as to what in general young people consider as being 'in' or 'out', $64 \%$ of the respondents stated that 'Europe' is 'in'. Even though the positive attitude towards Europe in general did abate slightly in comparison with 2002, the majority of young people in Germany approves of Europe. The older the respondents, the more they consider Europe to be 'in'. Since the interest in politics also increases with age, this increasing interest in politics in general seems to have a positive effect on the identification with Europe.

Regarding more specific attitudes towards the European integration process, almost all of the respondents (94\%) related the European Union to the 'freedom to travel, study and work'. For $87 \%$, the European Union stands for 'cultural diversity', $82 \%$ associate it with peace. Thus the major associations with the European Union are clearly positive. It is only in the fourth place that we find the first negative evaluation of the EU. $73 \%$ associate it with bureaucracy. $72 \%$ think that the EU implies an 'increasing influence in world politics', $64 \%$ associate it with the 'dissemination of money' (i.e. the Euro), $58 \%$ with a 'lack of border controls', $56 \%$ with 'unemployment' and $53 \%$ with 'more crime'. For less than half of the young people, the European Union stands for 'economic wealth' (47\%) and for 'social security' (33\%). Quite surprisingly, young people are least of all concerned that the European integration process would lead to an evaporation of local and national cultures. 
Figure 1. What young people in Germany associate with the European Union Young people in the age from 15 to 25 years.

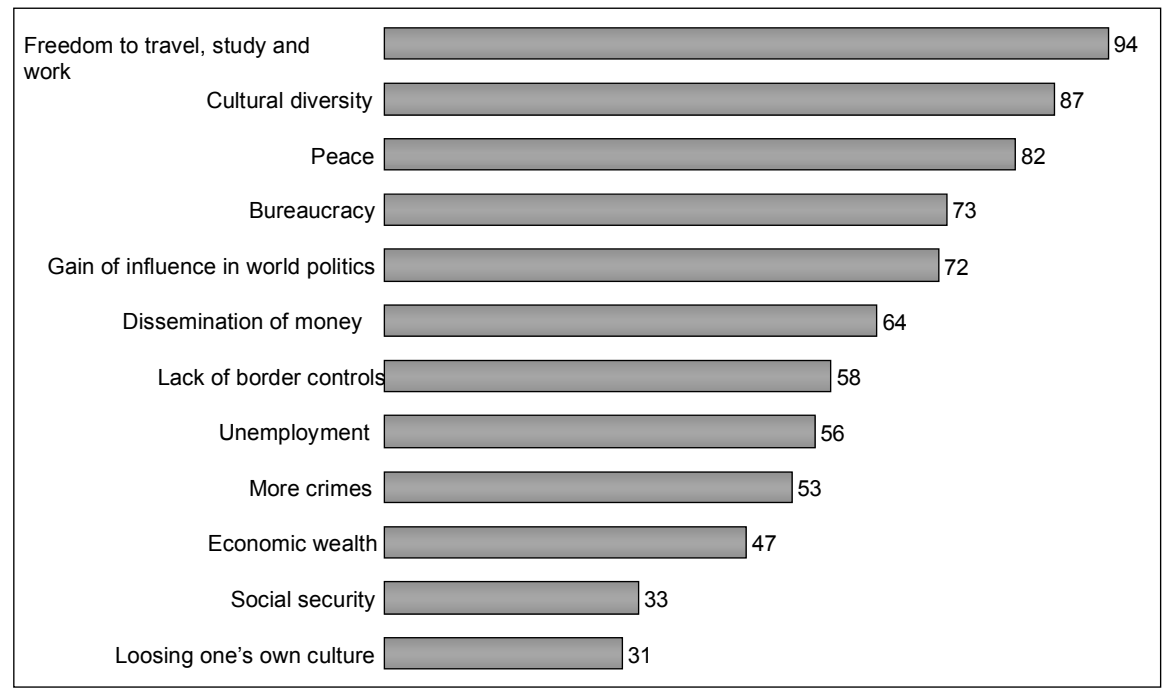

Source: Shell Jugendstudie 2006 - TNS Infratest Sozialforschung

In general, it seems that young people in Germany are most positively disposed towards the results of European integration on a cultural level as they value and enjoy the freedoms to travel around Europe, to study in another country, and to have the option to work in any EU member country they choose. Young people also cherish the increasing cultural diversity which results from these freedoms, i.e. the possibility to meet people from other countries in their hometown, at school, the workplace, or the university, as well as the greater variety of food, cultural events, languages and other products to be experienced in everyday life.

In contrast to this rather unequivocal appreciation of the cultural dimension of the European integration process, its results in an economic dimension are seen in a more sceptical fashion.

Not even half of the young people associate the integration process with an increase in economic wealth - i.e. with one of the main goals of the common market. Quite to the contrary, they seem to consider the European integration to be responsible for high unemployment rates and think that the EU's budget could be spent more efficiently.

The political results of the European integration process are again evaluated more positively. The initial goal of the European project, i.e. to establish a lasting peace in post-WW II Europe, is valued highly. Particularly the recent war in former Yugoslavia has strengthened the consciousness among young people in Germany that war can still take place in Europe. A slight majority of $51 \%$ even expresses a personal fear of another war in Europe (even though the current economic situation and the high unemployment rate are considered as more pressing matters). 
In comparison to the attitudes of young people, the population in Germany as a whole also primarily associates the EU with the freedom to travel, study and work within the EU (58\%) and with the opportunity to live in peace (53\%) (Eurobarometer 2005, p. 15). Yet the link between Europe and peace seems to be more pronounced among young people in Germany.

\section{Peace trough transnationalisation}

In order to judge on the relevance of the findings above it seems worthwhile to contextualise them within more general attitudes of young people in Germany towards globalisation and Germany's international orientation and its role in the world.

Although globalisation is primarily associated with the 'freedom to travel, study and work all over the world' ( $82 \%$ ) and with 'cultural diversity' (79\%), these two positive evaluations are immediately followed by two negative ones: a majority thinks that globalisation will also result in 'unemployment' (66\%) and 'more crime' (59\%). While $57 \%$ also associate globalisation with 'peace', this link is clearly weaker than in the case of the valuation of the European integration process as a peace project.

Almost three quarters of young people in Germanys $(72 \%)$ believe that the European integration process results in an increasing influence of the $\mathrm{EU}$ and its member states in world politics. The EU is also considered to be the political institution most likely to be able to control negative impacts of the globalisation process. When asked which organisations or groups they would trust 'altogether', 'to a certain extent', 'rather not' or 'by no means at all', to rightly handle and respond to the challenges of the globalisation process, the respondents put the EU in first place, even before the UN.

Figure 2. Confidence in the efficiency of providing solutions. "In which of the following organisations or groups do you confide altogether, to a certain extent, rather not or by no means at all, to rightly minister the process of globalisation?" ("Altogether / to a certain extent")

Young people in the age from 15 to 25 years who are familiar with the term globalisation (in \%).

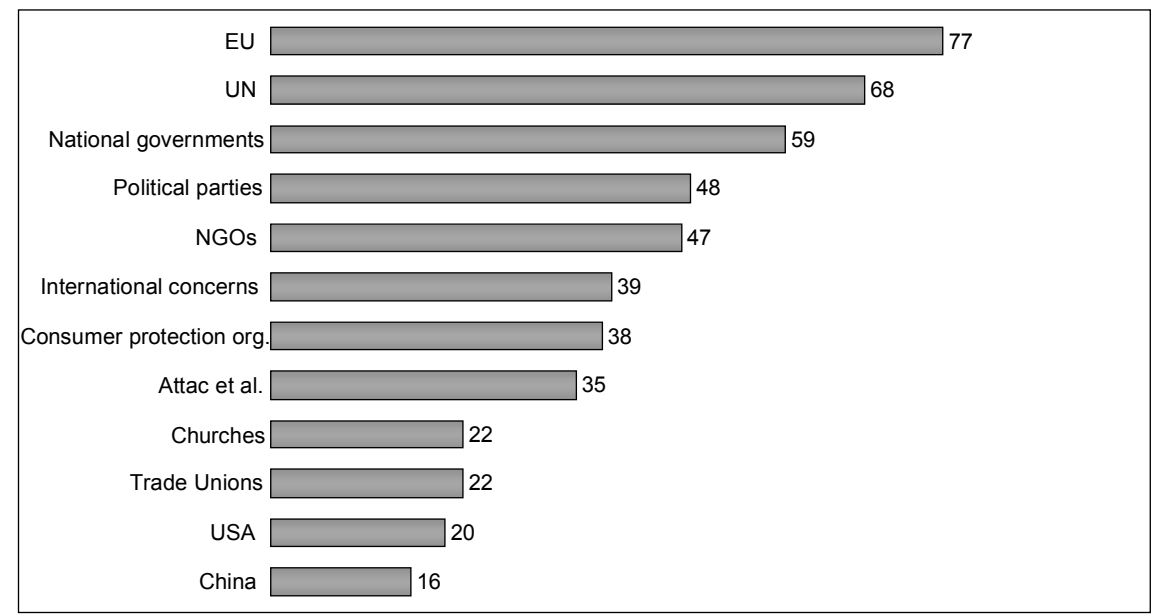


As figure 2 shows, young people not only express great reservations about the role which China and the US play in the globalisation process. They also consider the European Union to be the most important institution to rightly administer the effects of globalisation, even before the UN. One could, although in a highly preliminary fashion, conclude from these findings that young people in general value the EU's involvement in world politics and would support an even stronger involvement in the future. It is in this sense that it might also seem fair to say that in general the EU is increasingly perceived as a global political power rather than (merely) a global economic one. Expectations towards the EU seem to be high that it exerts its (growing) influence in order to help secure and establish peace, to find solutions for environmental problems, and to work against underdevelopment/ inequality on a global level.

Even if abstracting from the EU in particular it seems to be highly noteworthy that despite of the low interest they take in politics in general and despite their rather sceptical attitude towards politicians, young people express a high level of trust in governments and international governmental organisations to master the challenges posed by globalization - well before non-governmental organisations or movements critical of the globalization process (e.g. Attac).

Figure 3. What do young people in Germany associate with globalisation?

Young people in the age from 15 to 25 years who are familiar with the term globalisation (in \%).

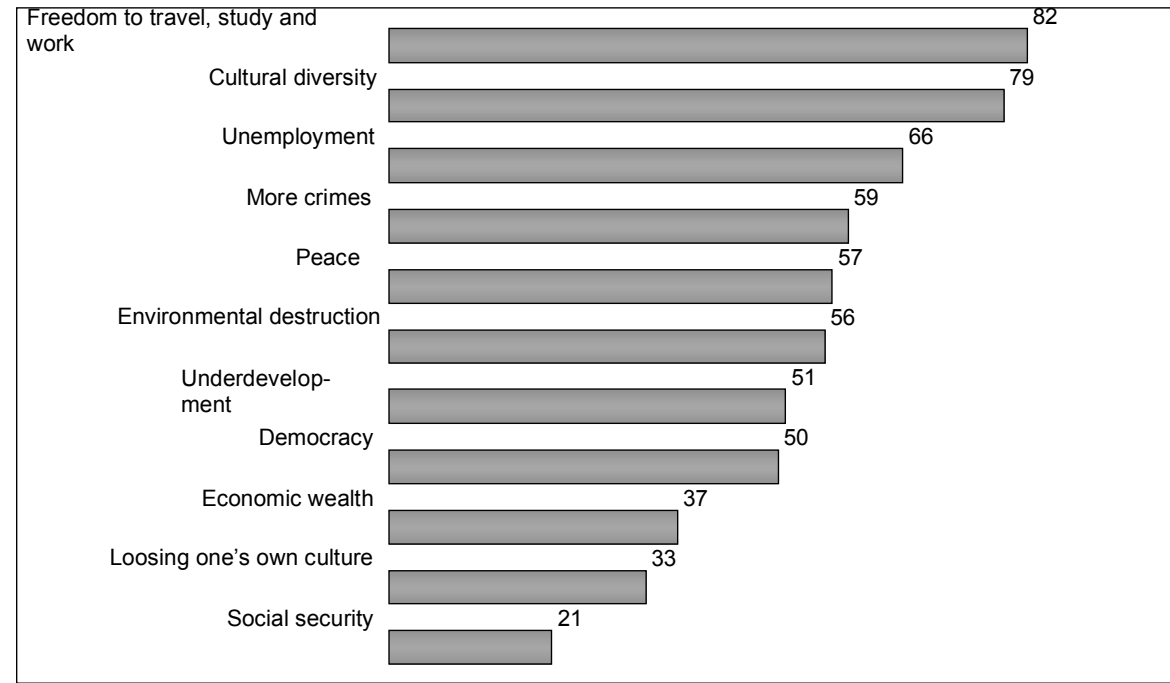

Source: Shell Jugendstudie 2006 - TNS Infratest Sozialforschung

\section{A declining euphoria for the EU as a single state}

Against the impression of the highly positive disposition towards the EU and its global role it is remarkable that within the course of only four years we witness a steep decline in the number of those who support the continuation of the European 
integration process in a 'deep' sense, i.e. in its resulting in a single European state (s. figure 4). In $2002,49 \%$ of the respondents supported the idea that the EU should develop into a single state in the future, while $28 \%$ rejected the idea and $27 \%$ were unsure as to whether to support the idea or not. In 2006, this attitude has changed dramatically: $45 \%$ now are opposed to the idea of the EU becoming a single state in the future, only $32 \%$ remain in favour and $23 \%$ are still undecided. Even although the topic of further 'deep' unification will not be on the political agenda for the foreseeable future given the failure of the first attempt to install a Constitutional Treaty, in general this shift in attitudes seems to signal a declining euphoria about the institutional aspects of the integration process in general.

Figure 4. Attitudes towards Europe

Should the European Union become one single state in the future?

Young people in the age from 15 to 25 years.

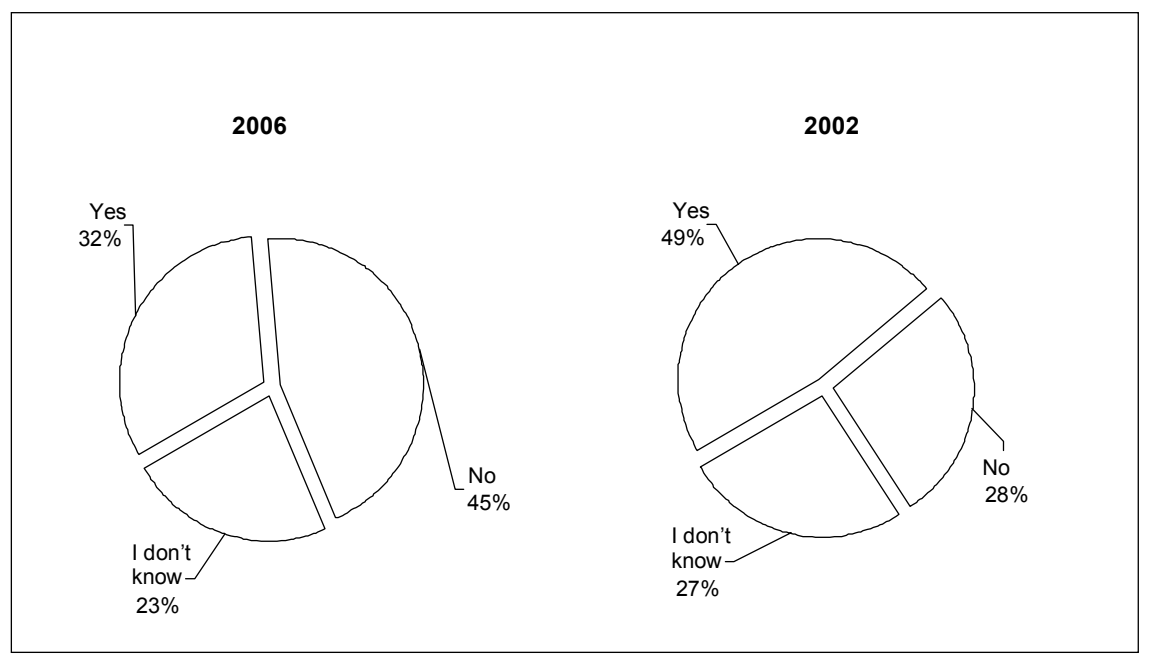

Source: Shell Jugendstudie 2006 - TNS Infratest Sozialforschung

We also find a growing scepticism against further EU enlargement. Whereas in 2002 the big round of Eastern Enlargement, with the admission of 10 new member states in 2005 , was favoured by $44 \%$ of the young people and opposed by $32 \%$, in 2006 only $19 \%$ would support an accession of Turkey while $61 \%$ would oppose it.

\section{Back to European basics}

Following up on the observations on attitudes towards further EU enlargement and particularly upon possible Turkish EU membership, analyses of the prevalent discourses on the Balkans and Turkey in relation to Europe demonstrate that the main arguments used to point out the 'incoherence' of the Balkans and Turkey refer to these states' claiming an 'anachronistic', 'heroic' identity, whereas Western Europe moved on to a post-heroic identity (Quenzel, 2005). Heroic cultures differ from post-heroic cultures as far as in heroic cultures social recognition can still be achieved through sacrifices made in armed struggle/war, while in post-heroic 
cultures the readiness to die for the Fatherland is no longer of social significance. According to the heroic/post-heroic thesis, this acceptance of individual sacrifice as a means to gain recognition is missing in current EU member countries particularly because of their negative relation - strengthened by and through the European integration process - to Europe's past as a war-torn continent. Particularly in the case of Turkey it is thus, for example, not the genocide on the Armenian people which is held against the country, but the collective denial of guilt - and thus its self-exclusion from a European 'community of memory' with an associated negative relation to the past (see, for example, Winkler, 2004 and Münkler, 2004).

It is in this sense that Giesen (2002: 208ff) points out that many Western nations have replaced triumphant founding myths with references to a traumatic past and that these memories include victims as well as perpetrators. These new traumatic foundations of collective memory contrast sharply with some post-war attempts to clean up a nation's image by claiming the guilt of another nation or of specific groups within a nation. This common memory of a traumatic past now provides Europe with a 'tacitly assumed moral consensus: an European collective identity based on the horror of the past' (ibid.: 209). The strong reaction of and within the EU to the right-wing Freedom Party (FPÖ) joining the Austrian government in 2000 can in this sense be interpreted as a reaction towards a challenge of this conception of a European self. We would like to argue that it is exactly this tacit agreement which is on its way to more and more become a part of a collective European identity not only among young people in Germany, but also among young Europeans in general.

We would like to illustrate this observation using but one prominent example in the form of recent activities of the European Youth Forum, a federation of more than 90 National Youth Councils and International Non-Governmental Youth Organisation which seeks to represent the interests of the young people in Europe. It would of course be wrong to see this Forum as representative for all young Europeans. However, its activities provide important clues as to the interests of those young people in Europe who take an active interest in the future shape of Europe. Indeed, since politically active young people often serve as opinion leaders, we may consider the declarations of the European Youth Forum as a potential seismograph for the attitudes of young Europeans towards the European integration process.

On the occasion of the 50th anniversary of the Treaty of Rome, the European Youth Forum, in March 2007 published the 'Rome Youth Declaration' (European Youth Forum 2007), a postulate in the name of all young Europeans concerning the state of the European integration process. At its very beginning, the 'Rome Youth Declaration' refers to the founding intentions of the European project, to ensure 'peace' in a war-torn continent: 'We, the young people of Europe, gathered in Rome on the occasion of the 50th Anniversary of the Treaty of Rome to pay tribute to and continue the vision of those who made it possible for us to grow up in an environment of peace and prosperity, democracy and rule of law' (ibid.). Thus the Treaty of Rome is highlighted as the reason why young Europeans can live in a peaceful and democratic Europe and indeed this vision of a peaceful Europe - or rather the con- 
tinuation of it - serves as the rationale for the convention in Rome and the ensuing declaration. This means that the initial intentions of Robert Schumann - expressed in his declaration of 9 May 1950 (Schumann 1950), which is considered the founding speech of the European Community - to create a lasting peace in Europe through a solidarity in the production of coal and steel between France and Germany that 'will make it plain that any war between France and Germany becomes not merely unthinkable, but materially impossible' are acknowledged by the young Europeans as the paramount achievement of the European Union.

In the following paragraph the 'Rome Youth Declaration' states that the EU is 'a place of equality, freedom, tolerance, and solidarity' and that the process of integration preserves uniqueness and diversity. Of special interest for our argument here are also the following paragraphs connecting the failure of the Constitutional Treaty with the challenges of globalisation. Read closely it contains a rather complex argument. It ascribes to the European project a loss of direction and inspiration which led to an increasing uncertainty and dissatisfaction among the European people; as a consequence, the rejection of the Constitutional Treaty by the voters of France and the Netherlands is interpreted as a reaction to a lack of vision. The European Union is further accused of not dealing adequately with the opportunities and serious challenges of globalisation. The European Youth Forum outlines its primary expectations towards a future European Union as follows: 'We want a European Union that promotes democratic values and Human Rights. We want a European Union that promotes sustainability, preserving our environment for future generations. We want a European Union that promotes the economic success and the social responsibility for all its citizens, especially the ones who are in greater need. We want a European Union that assumes its role in our globalised world' (European Youth Forum 2007).

Accordingly one of the main aims of the 'Rome Youth Declaration' is to make the European Union fit for future challenges by giving it direction and inspiration. And interesting enough the promotion of democratic values and human rights are emphasized in particular. Sustainability and environmental issues rank second on the agenda, followed by economic success and social responsibility. Similar to the results of the Shell Youth Survey 2006 it seems that young people from all over Europe do not consider European integration primarily as an economic project. Here too the cultural and political achievements and especially the idea of Europe as a peace project are acknowledged as centre pieces of European integration.

\section{Peace and democracy as a cornerstone of a European identity}

If we follow the idea that the formation of a collective identity requires a self-description of the community as an entity and hence the confinement against others not belonging to one's community (see for example Lepsius 1997: 949ff; Anderson 1983; Hall 1994: 196f, Laclau \& Mouffe 1991: 164), then a European identity needs a self-description as an entity and ideas of what distinguishes Europe from other parts of the world. As Glynis Breakwell (2004: 34) points out: 'One main problem with describing the character of the identity element that might be generated by EU 
membership is that the EU as a category in itself is changing.' The history of the European integration is also the history of its enlargement. The six founder states from 1958, Italy, France, the Netherlands, Belgium, Luxemburg and Germany, were joined in 1973 by the northern countries Great Britain, Ireland and Denmark. The south of Europe followed with Greece in 1981 and Spain and Portugal in 1886. The EFTA-countries Sweden, Finland and Austria joined the EU in 1995. 2004 followed the so called 'Eastern enlargement' with Cyprus, Latvia, Lithuania, Estonia, Hungary, Malta, Poland, Slovakia, Slovenia, and the Czech Republic. The newest members, Bulgaria and Rumania, joined in 2007. The permanent change of the borders of the European Union precludes a perception of the European Union as a fixed entity. And the discussion about the borders of the European Union is not likely to disappear over the next years. Currently the accession of Turkey to the European Union dominates the discussion. Yet the list of potential accession countries includes Albania, Bosnia-Herzegovina, Croatia, Island, Macedonia, Moldavia, Norway, Russia, Switzerland, Serbia and Montenegro, the Ukraine, Belarus, and also Israel. This list in itself demonstrates that the discussion about the borders of the European Union is not likely to abate in the near future.

As Castano (2004: 41ff) demonstrated in a series of experiments, the perceived 'entity-ness' of a community is a critical factor for a positive identification with Europe. Presenting the EU as having fuzzy borders to the participants in the experiments did reduce their level of identification dramatically (ibid.: 48f). However, in order to perceive the European Union as an entity it is not necessary for it to fulfil the criterion of cultural homogeneity. In contrast to many other political communities, cultural or even ethnic homogeneity is not considered as the basis of the European community. The European integration process was initiated to avoid the negative consequences that followed from a strong nationalism based on the idea of cultural and ethnic homogeneity, thus consequently diversity and not homogeneity serves a basic principle underlying the European Union. Castano (ibid.: 43f) further argues that what mediates a common identity is not whether it is homogeneous or not, but the extent to which it acquires a psychological existence, in other words a self-representation as an entity at a collective level. One way to acquire a psychological existence in the minds of the Europeans is to behave as an actor and to be recognized as such by other actors, like the U.S, Russia, China, and the UN etc.; and that this recognition first took place during the war in Yugoslavia, when the EU was acknowledged by the UN as a political actor (ibid.:53).

During the last years the EU increasingly acted as political actor on a global stage and could thus be perceived as an entity possessing intentionality and the capacity of action in world politics. The perception of the EU as a global political actor gaining influence, but also disillusions regarding world political events (e.g. the war in Iraq), could help to explain why expectations towards the EU as an actor in global politics have risen among younger people.

\section{Conclusion}

As we were able to show with data drawn from the Shell Youth Survey 2006, Europe is widely appreciated by young people in Germany. Their main association 
with the European Union are positive and refer primarily to the cultural and political impacts of the integration process, i.e. the freedom to travel, study, and work with in the European Union, cultural diversity, and peace. This means that young people in Germany are rather positively disposed towards the cultural and political achievements of the integration process than on its results on the economic level, which are seen more sceptically. The representatives of the European youth organisations refer even more clearly to the European integration as a peace project. In accordance with the attitudes of the young people in Germany they also point out cultural diversity as an important part of the European identity. Their vision for Europe is a European Union as promoter of democratic values, human rights, sustainability, economic success, and social justice and they support and indeed ask for an increasing role of the EU in world politics. Young people in Germany also consider the European Union as the institution in order to control the negative impacts of the globalisation process. Thus both groups agree in seeing the EU as a global political power rather than merely an economic one and they express their expectation towards the EU to exceed its growing influence in order to help to secure and establish peace, find solutions for environmental problems and work against social injustice on a global level.

On the other hand (and here we only have data from young people in Germany), we witness a declining support for the 'deepening' process of the European integration. This indicates a declining euphoria about the further transmission of sovereign national rights to the European Union among young people. In addition we find a growing scepticism against further EU enlargement.

Taken together, these attitudes towards the European integration process seem rather contradictory: Young people in Germany value the cultural and political achievements of European integration, they expect the EU to become more influential in world politics and to regulate the negative impacts of the globalisation process, yet they disapprove of the 'deepening' as well as of the 'enlargement' process.

However, the attitudes appear to be less contradictory if we accept Giesen's (2002: 208ff) concept of a moral consensus, based on the European experiences of war and genocide, as a common European identity. Thus we can understand the importance of democracy and human rights as a dominant part of the European self-description and also the claim towards the European Union to secure and establish peace, advance democracy and work against social injustice. The rejection of a homogeneous culture as foundation of European identity and the distinct approval of cultural diversity and of tolerance as a dominant part of the European self-description may underlie some more sceptical dispositions towards the deepening process.

Yet the self-description as a community which has learned from its past and which took political action to prevent war and genocide, and which is commited to the values of democracy and tolerance as well as to the Human Rights is not only the foundation of the integration process. In contrast to a self-description as a continent with a shared ethno-cultural history, i.e., for example, as a Christian community, it allows to perceive the EU as a political actor that had the capacity to establish lasting peace in a war-torn continent and that is able to exert its influence in this 
manner on a global level as well. In this way the European Union can be perceived as an entity even though its borders did change frequently in the past and will change again in the future.

The self-description as a moral community also fulfils the symbolic need for a sense of transcendence. Peace, democracy and the human rights are considered as universal values. They are values in and for themselves. Even though these values were frequently violated during history, this does not diminish their validity. Thus the identification with Europe as a community of moral consensus allows the individual to be part of a concept that outlasts its own physical existence.

By way of conclusion we would like to emphasize once more that the argument presented here does not at all claim to have extrapolated future trends of the European integration process from representative data covering European society as a whole. Rather, we have taken some remarkable empirical findings regarding the attitude towards Europe among young people in Germany as a starting point to engage in what can be little more than a theoretically informed speculation about a future European Union which might see its increasing role in world politics to be accompanied by a (re-)construction of its identity 'back to basics', i.e. a sharper focus on and a self-understanding as a peace project. This is not to argue that this is the best what the EU or the construction of a European identity can hope for. But if additional research could show that what we can suspect looking at the young generation of the EU's largest member country can also claim validity on a wider European scale, then it is certainly not the worst it can hope for as well.

\section{Literature}

Anderson, B., 1983. Imagined communities: reflections on the origin and spread of nationalism: Verso Ed.

Breakwell, G., 2004. Identity change in the context of the growing influence of European Union institutions. In R. Herrman, Th. Risse \& M. Brewer, eds. Transnational identities: becoming European in the EU. Lanham et al.: Rowman \& Littlefield, p. 25-39.

Castano, E., 2004. European identity: a social-psychological perspective. In R. Herrman, Th. Risse \& M. Brewer, eds. Transnational identities: becoming European in the EU. Lanham et al.: Rowman \& Littlefield, p. 40-58

Deutsche Shell, 2006. Jugend 2006: 15. Shell Jugendstudie. Conceptualization and coordination by K. Hurrelmann, M. Albert \& TNS Infratest Sozialforschung. Frankfurt/M.: Fischer Taschenbuch Verlag.

Diez, Th., 2004. Europe's others and the return of geopolitics. Cambridge Review of International Affairs, 17(2), p. 319-335.

Diez, Th., Stetter, S. \& Albert, M., 2008. Introduction. In Th. Diez, M. Albert \& S. Stetter, eds. The European Union and border conflicts. Cambridge: Cambridge University Press. (forthcoming).

Eurobarometer 63.4, 2005. Die öffentliche Meinung in der Europäischen Union. Available at: http://ec.europa.eu/public_opinion/archives/eb/eb63/eb63_nat_de.pdf [accessed 03 May 2007].

European Youth Forum, 2007. Rome Youth Declaration. Available at: http://europa.eu/50/ docs/ro-me_youth_declaration_en.pdf [accessed 17 May 2007]. 
Giesen, B., 2002. Constitutional practice or community of memory: some remarks on the collecitive identity of Europe. In D. Sachsenmaier, ed. Reflections on multiple modernities. Leiden et al: Brill, p.193-216.

Hall, S., 1994. Rassismus und kulturelle Identität: ausgewählte Schriften 2. Hamburg: Argument-Verlag.

Laclau, E. \& Mouffe, Ch., 1991. Hegemonie und radikale Demokratie: Zur Dekonstruktion des Marxismus. Wien: Passagen Verlag.

Lepsius, R.M., 1997. Bildet sich eine kulturelle Identität in der Europäischen Union? Blätter für deutsche und internationale Politik, 8, p. 948-955.

Manners, I., 2002. Normative power Europe: a contradiction in terms? Journal of Common Market Studies, 40(2), p.235-258.

Münkler, H., 2004. Helden wie nie. Der Tagesspiegel, 21 April.

Quenzel, G., 2005. Der Balkan im europäischen Identitätsdiskurs: zur kulturellen Legitimierung der EU-Außengrenzen. In J. Meyer, R. Kollmorgen, J. Angermüller \& D. Wiemann, eds. Diskurse der Gewalt: Gewalt der Diskurse. Münster: LIT, p.127-139.

Schumann, R., 1950. Declaration of 9 May 1950. Available at: http://europa.eu/abc/ symbols/9-may/decl_en.htm [accessed 17 May 2007].

Winkler, H.A., 2004. Selbstzerstörung inbegriffen. Frankfurter Rundschau , 1 March. 